\title{
Factors Affecting Individual Resilience
}

\author{
A. Wahyudi \& S. Partini \\ Universitas Ahmad Dahlan, Yogyakarta, Indonesia
}

\begin{abstract}
Resilience is a skill ability, knowledge, or insight that acts as an individual effort to overcome difficulties and to face future challenges. This study seeks to explain several factors that affect individual resilience. The method used in this study is literature study. Data were analyzed using descriptive analysis. By knowing the factors that affect the resilience, this study hopes that a counseling teacher can help the students develop their resilience.
\end{abstract}

\section{Keywords-Affect Individual Resilience}

\section{INTRODUCTION}

Humanare one of Allah's creatures has certain roles in their life. In the process of performing such roles, humans often face many barriers in which those are given for knowing how far the level of individual faith to Allah. Allah Almighty says "And really We will give you a test with a little fear, hunger, lack of wealth, soul and fruits. And give joy to the patient (Al Baqoroh:155)"

Shihab (2012) says that the word "We will indeed test you" implies that the essence of the life is marked by the inevitability of the existence of various trials [14]. The physical and psychological potentials provided by Allah can be used to develop individual resilience because developing resilience is a kind of gratitude for what Allah has granted to humans. Besides, patience is also important in facing, because it is a part of the devotion to Allah (Amien, 2016)

The rise of well-tested human through fear, hunger, lack of wealth, soul and fruits, and many disturbing disorders is an indicator of resilience because resilience itself is defined by "self-righting tendencies "of the person," both the capacity to be bent without breaking and the capacity, once bent, to spring back "[1]. This definition shows that resilience is the capacity to keep trying and rising from the faced problems and to be good without breaking the rules in force.

In line with that opinion, the other opinion about resiliency says that "resilience means the skills, abilities, knowledge, and insight that accumulate over time as people struggle to surmount adversity and meet challenges. It is an ongoing and developing fund of energy and skill that can be used in current struggles ". (Garmezy, 1994 in Saleebey, 1996, in Amien, 2001:298). Based on the explanation above, the writer is interested to write this topic by using the existing literature review of the factors that affect individual resilience. This study hopes that the known factors that affect resilience can assist the institution in developing the resilience furthermore.

\section{METHOD}

This paper is prepared using a literature study approach. Data analysis uses the descriptive method. This study refers to numbers of references that relate to individual resilience topic.

\section{RESULTS AND DISCUSSION}

Individual's resilience does not happen by itself but is influenced by many factors. Some experts suggest some factors affecting resilience such as Tedeschi and Kilmer 2005; Bonanno et al 2007; Hegney et al 2007; Boardman et al 2008. The experts argue that resilience is strongly influenced by several things namely 1) good interpersonal relationships, 2) social relationships and confidence to continue to expand relationships with other individuals, 3) having internal resources such as optimism and positive thinking, and 4) high spirituality includes religiosity $[15,10,5]$. These factors are further explained by Barbara, Lisa and Karen (2011) they describe that individuals who have resilience can rise if [4]:

1) Having good interpersonal relationships includes the interaction of individuals with family, friends and work colleagues. This relationship will have a positive impact to individual who experience the problem. The physical assistance given by them at least is able to minimalize the individual memory of the problems that occur. The assistance provided by family, friends and colleagues is also a means to reduce the tension of anxiety, tension or depression that can occur in individuals who have problems.

2) Having confidence is a supporting factor for individual resilience. The setting of a strategy for every individual goal can also make individuals have confidence without having supports, of which further will only make individual business overcoming problems faced ineffectively.

3) The views of Harris (2008) and Greene \& Graham (2009) show that a thinking and a focus of positive things are more emphasized in the formation of resilience because the individual will have a sense of optimism with a focus on positive things, but further they argue that individuals who have problems will not focus on the negative things $[9,8]$.

4) In this context Barbara's spirituality, Lisa and Karen, (2011) and Stefano. L \& Daniele. M (2017) reveal the meaning of spirituality encompassing many things that this spiritual activity makes people able to form world peace. Of course this view needs to get additional, because in the context of 
Islamic religion, spritulitas is closely related to the activity of individuals in carrying out their religious activities or known as taqwa. The process of worshipping is part of individual beliefs, meaning that spirituality must be accompanied by a belief in Allah so that spritulitas can provide the benefits for individuals both in the world and in the Hereafter.

Some scholars have defined the term resilience as the ability of individuals to be able to rise and survive in various problems. Human life can not be separated from problems. Sutoyo (2009:92) says that in Islamic view if the problem is given to the believers, the problem may be a test; if the problem affects the ordinary people it may be a reminder for returning to the path that has been determined by Allah, but if the problem occurs in humans who always do damage, the problem is a punishment from Allah "And indeed We will test you with a little fear, hunger, lack of wealth, Soul and fruits. And give joy to the patient" (Al Baqoroh:155) and Richardson (2002);Bonanno (2004) state that resilience as an individual's ability to maintain healthily and stability of physical and psychiatric conditions and is able to rise from negative emotional experiences due to difficult events.

Meanwhile, ARadke-Yarrow and Brown (in Meyer and Jeannette, 2002:19) "resilience are seen as the survival ability of individuals to predict and rise from the problems at hand. While no resilience is seen as individual inability to survive the problems it faces from time to time" [12]. In line with that opinion Allen and Unwin (2003: 6) states that "the problem is a sprit in life, there is no life without problems, only the problem is how the individual's ability to rise from adversity over problems faced" [2]. This view indicates that the rise up of the individual becomes one of the important factors that must be owned by the individual in facing the problem, further Allen and Unwin (2003) tell how a mother can rise from adversity when the country inhabited the mother must experience colonization from other country and must flee to another country [2]. Living in a colony is not a pleasant one because the colonies can not determine independence in life. Allen and Unwin (2003) reported that the there is a mother can pass through it and become a strong person after colonization, perhaps that's why Allen and Unwin (2003) take the writing of Anne Dawson who writes that "resilence is about facing adversity with hope. We In habit one world in which we are all deeply connected. I hope for the wisdom and justice which will bring us peace". Further Jenifer R. Riley and Ann S Masten (in Ray Dev, Bonnie and Robert, 2005: 13) suggested that the resilience"Tothe pattern of positive individual adaptation in the face of the problems. There are at least two conditions to describe the resilience of are a) individual readiness in adapting to the problems that have occurred and b) the ability in facing the problems ".

The readiness of the individual is very important when dealing with the problem as the ready ones will quickly adjust to the problems that are facing, because Allah Almighty has said "Then indeed after difficulties there is ease" (AsySyarh :5). This verse of the Qur'an provides information that every problem is always has many solutions, so that individuals who are experiencing problems are asked to find a way out and be patient with the problem being faced.

\section{CONCLUSION}

The development of individual resilience is very important to be done so that the individual can survive and rise from the problems he faced. As a guidance and counseling teacher, it is important to know the factors that influence individual resilience, to support and create an atmosphere that can foster individual resilience. In addition, knowledge of the factors that affect individual resilience can make the individual do his best to get out of the problems it faces by getting support from people who love him, a good friendship environment so hopefully, the individuals who are initially slumped due to having problems can rise and succeed in the future.

\section{REFERENCES}

[1] Adrian DuPlessis VanBreda. Riselence Theory: A Literature Review. Pretoria, South Africa: South African Military Health Service, Military Psychological Institute, Social Work Research \& Development. 2001.

[2] Allen \& Unwin. Risiliece. National Lebrary Australia. Australia, 2003.

[3] Anwar, Sutoyo. Bimbingan dan Konseling Islami.Widya Karya. Semarang, 2009.

[4] Barbara R,Lisa P.G \& Karen A.R (editors). Resilience In Aging :Concepts, Researc, and Outcomes. Springer. New York. 2011.

[5] Boardman JD, Blalock CL, \&Button TM. Sex differences in the heritability ofresilience. Twin Research and Human Genetics, 11(1), 1227. 2008.

[6] G.A. Bonano, Loss, trauma, and human resilience have e underestimate the capacitythrive after extremely aersive events ? American Psychologist, 59, 20 -28. 2004.

[7] Bonanno GA, Galea S, Bucciarelli A, \&Vlahov D. What predicts psychological resilienceafter disaster? The role of demographics, resources, and life stress.Death Studies, 31(10),863-883. 2007.

[8] R.R. Greene \& S.A. Graham, Role of resilience among Nazi Holocaust survivors: Astrength-based paradigm for understanding survivorship. Family and Community Health, 32(1 suppl), S75-S82. 2009.

[9] P.B. Harris, "Another wrinkle in the debate about successful aging: The undervaluedconcept of resilience and the lived experience of dementia," International Journal of Aging and Human Development, vol. 67, no. 1, pp. 43-61, 2008.

[10] D.G. Hegney, E. Buikstra, P. Baker, C. Rogers-Clark, S. Pearce \& H. Ross, et al. Individual resilience in rural people: A Queensland study, Australia. Rural and Remote health, 7(4),620-625. 2007.

[11] Lassi Stefano \& Mugnaini Daniele, "Role of Religion and Spritulity on Mental Healt and Resilience: There is Enough Evidence," International Journal of Emergency Mental Health and Human Resilience, vol. 17, no.3, pp. 661-663, ISSN 1522-4821, 2017.

[12] Meyer \& Jeannette. Resilience and development Positife Life Adaptations. Kluwe Academic Publishers. New York, 2002.

[13] Ray Dev,Bonnie \& Robert. Resilience in Children, Families, and Comunities. Plenum Plublisher. New York, 2005.

[14] Shihab, Tafsir Al Misbah.Lentera Hati. Jakarta, 2012.

[15] Tedeschi RG \& Kilmer RP. Assessing strengths, resilience, and growth to guide clinical interventions. Professional Psychology: Research and Practice, 36(3), 230-237, 2005.

[16] Amien,Wahyudi, "Iman dan Taqwa Bagi Guru Bimbingan dan Konseling," Jurnal Fokus Konseling, vol. 2, no. 2, pp. 89-98, 2016. 